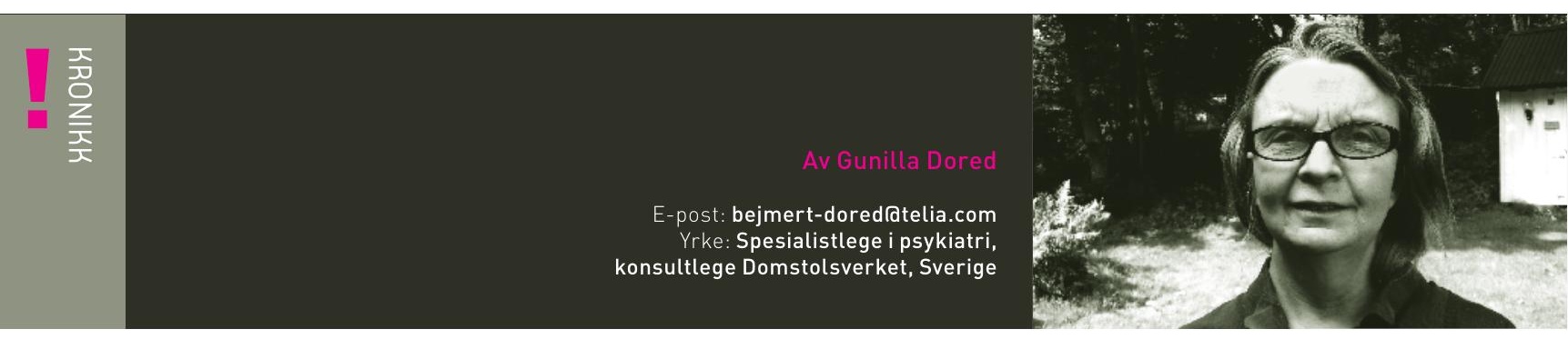

\title{
Et Faglig blikk på empati
}

\author{
> Helsepersonells evne til empati og etisk holdning \\ er et interessant og viktig område.
}

Litteraturen jeg henviser til i denne artikkelen viser at det er nødvendig med ytterligere forskning på dette temaet. Det er viktig at fremtidig forskning belyser ulike sider ved empati og etisk holdning på en måte som kan være interessant både $\mathrm{i}$ et forsknings- og utdanningsperspektiv.

Etter 30 års erfaring som lege i Sverige og Norge har jeg gjort meg noen refleksjoner rundt empatibegrepet og den betydning empati og medfølelse har for medisinsk behandling, et svært interessant fagområde slik jeg ser det.

\section{MøTE MED PASIENTEN}

Hva handler empati, det vil si medfølelse med pasienter om? Den populærvitenskapelige boken «Tillsammans» av professor Åsa Nilsonne og psykolog Anna Kåver (1) har hjulpet meg til å besvare dette spørsmålet. Her gjør forfatterne en enkel symbolsk sammenligning: $\AA$ ha empati med et medmenneske er å "gå i det andre menneskets tårn og se utsikten derfra, og så går man tilbake til sitt eget tårn og gjør det man synes er greit (vedtak)».

Mine antakelser er at hvis pasienten opplever møtet med helsepersonellet som positivt er det større sjanse for at man får informasjon som er viktig for den medisinske vurderingen. Hvis pasienten derimot opplever møtet som negativt kan det være vanskelig for vedkommende å snakke åpent og da får man kanskje ikke denne informasjonen. Det er ikke alltid enkelt å snakke om sykdom, selv om dette selvsagt er personavhengig. Jeg tror det kan være vanskeligere å snakke om redsel for å være smittet av hiv eller at man hører stemmer i hodet, enn om brystsmerter. De norske sosiologene Dag Album og Steinar Westin har vist (2) at ulike sykdommer har forskjellig status blant leger og medisinstudenter. Det gir for eksempel høyere status å arbeide med pasienter som har brystsmerter og trenger torakskirurgi, enn å arbeide med pasienter som har angst og psykiske lidelser. Dette kan påvirke møtet mellom pasienter og helsepersonell.

\section{STIGMA OG FORDOMMER}

Empatiforskningen kan bidra til å øke forståelsen for pasientens medisinske problemer. Det kan være vanskelig for pasienten å bli møtt med stigma og fordommer. Et negativt møte kan påføre dem angst og krever "psykologisk energi» og tid. Min erfaring tilsier at det fortsatt er store stigmaproblemer knyttet til psykisk sykdom.

Bruk av empati handler ikke bare om å få informasjon fra pasienten, men også om at pasienten skal føle at han eller hun møter forståelse og respekt. Det er også viktig at pasienten forstår «vedtaket», det vil si behandlingen, og at behandler og pasient har en best mulig allianse i dette. Det kan bli uryddig hvis pasienten er usikker på behandlingen. Pasienten kan for eksempel bli usikker dersom han eller hun ikke forstår hva som skjer («Skal jeg på røntgen nå, hva skjer der og hvorfor fikk jeg denne tabletten?»). 
Hva handler empati, det vil si medfolelse med pasienter om?

At helsearbeideren formidler realistisk håp har også betydning for hvordan behandlingen forløper. En svensk undersøkelse av fysioterapeut Pia Thomee med kolleger har vist at hvis en pasient har tro på seg selv etter ett benbrudd, så øker muligheten for en bedre rehabilitering (3).

Det ligger psykologisk energi i empati og formidling av håp. Dette viser også at man må være ydmyk når det gjelder ortopediens fagkunnskap og resultatet av en operasjon, men at resultatet kan bli bedre hvis pasienten tror på seg selv.

\section{MAKTFORHOLD}

Fokus på empati og anvendelse av «tårnmodellen» kan også hjelpe helsepersonell med å forstå at pasienten er i sitt eget «tårn» og at det finnes to "tårn». Sykepleieren på ortopeden som går mye i fjellet kan for eksempel støtte og formidle håp til pasienten som akkurat har begynt å gå etter et benbrudd. Rehabilitering er en «trapp» med forskjellige faser. Det gjelder å se rehabilitering ut ifra den fasen pasienten befinner seg i.

Sykdom er også forbundet med maktforhold og hierarki mellom pasient og behandler. Å ha empati og "gå i tårn" kan kanskje øke erkjennelsen av at pasienter har «fagkunnskap om egen sykdom og forstår den». I dag har pasienter foreninger og kan søke kunnskap på internett, noe som ikke var mulig for 30 år siden. Jeg synes dette er greit.
For helsepersonell handler det om å kombinere fagkunnskap og empati. Disse størrelsene er gjensidig avhengige av hverandre.

Arbeidsmiljøet er også viktig for at møtet mellom helsepersonell og pasienter skal fungere godt. For mye stress kan påvirke helsearbeidernes mulighet til å ta seg nok tid og føre til at møtet med pasientene oppleves som et ork. Dette er selvfølgelig ikke bra. I det følgende gir jeg en oversikt over noen avhandlinger om empati som er skrevet i de senere årene for å understreke empatibegrepets betydning innenfor forskningen.

\section{ETISK KOMPETANSE}

I en ny avhandling «Empathy in medicine. A philosophical hermeneutic reflection", Universitetet $\mathrm{i}$ Oslo (4) beskriver lege Reidar Pedersen såkalte «missing links» i litteraturen når det gjelder utvikling av empati i medisinsk utdanning. Pedersen ser nærmere på begreper som empati og moralsk vurderingsevne, biomedisinsk fagkunnskap og vurderingsevne, vitenskap og paradigmer og den personlige, sosiale og historiske bakgrunnen til den som tar utdanningen. Pedersen spør om ikke disse begrepene bør knyttes bedre sammen i fremtidig medisinsk utdanning og utvikling, slik at man kan oppnå bedre resultater. Han viser at økningen i evnen til empati, som det kan være behov for i løpet av utdanningen av helsearbeidere, er mindre enn ønsket.
To artikler i den svenske Läkartidningen uttrykker tilsvarende interesse for å utvikle den etiske kompetansen og evnen til empati hos medisinstudenter. Artiklene har titlene "Att utveckla etisk kompetens - går det?» (5) og «Studenter behøver få träna etik under klinisk praktik» (6). Det er med andre ord flere som har fattet interesse for disse behovene.

Psykolog Jakob Håkansson Eklund ved Mälardalens høgskola har startet et empatisenter (www.emphaty.se) og har gjort flere undersøkelser $\mathrm{i}$ forbindelse med sin avhandling. Blant annet har han studert hvordan evnen til empati påvirkes av informasjonen vi får om en pasient før vi møter ham eller henne. Ifølge denne undersøkelsen kan det for eksempel være en større utfordring å forstå og føle empati for en kriminell pasient enn for en pasient som er et offer (7).

\section{ETNOKULTURELL EMPATI}

Håkansson Eklund har også observert at vår evne til empati påvirkes positivt når vi har hatt lignende psykologiske erfaringer i vårt eget liv (8). Kanskje trenger det ikke å være en ulempe for den som arbeider i psykiatrien, å ha hatt en depresjon selv? Selvfølgelig er det også mye annet som kan påvirke evnen til empati.

Psykolog Chato Rasoal har skrevet en avhandling om etnokulturell empati, det vil si hvordan vi foler empati med mennesker med en annen etnisk 
bakgrunn (9). Han undersøker 365 studenter under forskjellige typer medisinsk utdanning (lege, psykolog, sosialarbeider, sykepleier) og deres evne til empati. Såkalt grunnempati (basic emphaty) måles i denne undersøkelsen med instrumentet Interpersonal Reactivity Index-IRI (Davis 1983), og det som kalles etnokulturell empati måles med Scale of Ethnocultural Emphaty-SEE (Wang et al., 2003).

Når Rasoal sammenligner og vurderer fakta, det vil si svarene fra de to spørreskjemaene, ser han en betydelig sammenheng mellom grunnempati og etnokulturell empati (overlapping). Hvis en student har stor evne til empati ifølge IRI-skalaen, er sannsynligheten stor for at han også har stor evne til etnokulturell empati ifølge SEE-skalaen. Rasoal ser en noe større evne til empati hos psykologi- og sosialarbeiderstudenter, men er ydmyk og usikker med hensyn til resultatenes signifikans ettersom det er små forskjeller og små grupper. Han ønsker generelt mer forskning på området.

\section{PASIENTENS OPPLEVELSE}

I forskningen som er presentert i denne artikkelen så langt, har man målt evnen til empati hos forskjellige helsearbeidere og studenter, men pasientenes opplevelse av å bli møtt med empati er ikke målt. I fremtidig forskning vil det derfor være svært interessant å måle pasientenes opplevelse av å ha bli møtt med empati og knytte dette sammen med resultatene man har oppnådd i undersøkelser der man med ulike skalaer har målt evnen til empati hos helsepersonell.

I en studie av sykepleier Sandra Pennbrant er også pasientenes og de pårørendes opplevelse av møtet med legen målt (10). Hun har intervjuet leger, eldre pasienter og pårørende. Samtalene er tatt opp og deretter analysert. Man har kodet samtalene og delt dem inn i temaer for å analysere innholdet. Analysen av innholdet $\mathrm{i}$ intervjuene og vurdering av dialogene viser at legenes møter med eldre pasienter og pårørende ikke har vært så gode. En mulig årsak til dette kan ifølge forfatteren være hierarki og at pasienter og pårørende opplever maktforhold som gjør at de ikke får den dialogen eller det møte med legen som de ønsker. Forfatteren skriver også at 20 pasienter er intervjuet, og man må selvfølgelig vurdere ytterligere forskning med flere pasienter i fremtiden. En mulig årsak som forfatteren også vurderer, er at legen har dårlig tid og er stresset. Det har vært store innsparinger i det svenske helsevesenet i mange år. Disse resultatene er bekymringsverdige og viser hvor viktig empatiforskningen er. De viser også at arbeidsmiljøet er viktig. Når pasienter opplever møtet med helsepersonell slik som i Sandra Pennbrants undersøkelse, kan den medisinske behandlingen påvirkes negativt og det er viktig at pasienter får en trygg og sikker behandling.

\section{PÅRøRENDE SOM RESSURS}

Også sykepleier Lena-Mari Sjöblom har på samme måte intervjuet pasienter, pårørende og helsepersonell (vernepleier og sykepleier). I denne avhandlingen ønsket hun å vurdere situasjonen som pårørende til pasienter med psykisk sykdom er i. Etter en innholdsanalyse kom hun fram til at de pårørende ofte er $\mathrm{i}$ en situasjon der de opplever mye stress, ettersom de er bekymret for den som er syk. I flere tilfeller (16 pårørende og 20 ansatte er intervjuet) gir pårørende og pasienter uttrykk for at de ønsker å bli ivaretatt bedre og få mulighet til flere møter. Samtidig må taushetsplikten naturligvis overholdes. Denne forskningen viser at pårørende kan være en ressurs som kan brukes og møtes på en bedre måte. Helsepersonell kan få viktig informasjon om sykdommen fra de pårørende, og ettersom psykisk sykdom er stigmatisert i samfunnet er det også spesielt viktig at pårørende til psykisk syke får støtte slik at de kan håndtere sin egen situasjon.

Empati og etisk holdning er også et fagområde innenfor den nevrobiologiske forskningen, og forskning om speilnevronenes betydning for evnen til empati er et fagområde i utvikling. En gruppe som arbeider sammen med professor Giacomo Rizzo- 


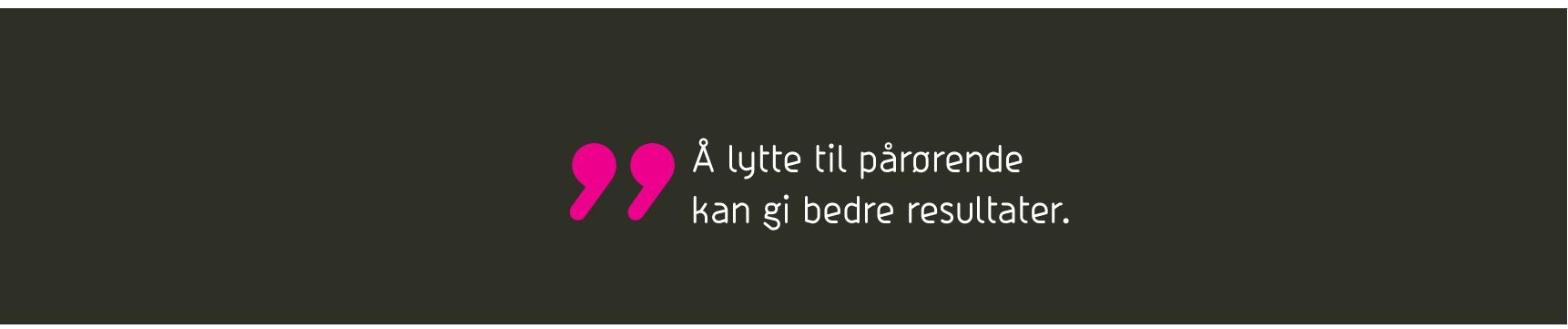

latti i Parma har med dyreforsøk vist at når en ape ser en annen ape spise frukt reagerer nevronene på tilsvarende måte som når den selv spiser frukten (12). Følelser smitter. Ivan Pavlov fikk Nobelprisen i 1904. Hans forskning har hatt stor betydning for forståelsen av hvordan vi lærer oss noe nytt. Kanskje kan forskning på speilnevroner også kan lære oss noe nytt og hjelpe oss til å forstå at mennesker er forskjellige.

\section{OPPSUMMERING}

Forskning på helsepersonells og studenters evne til empati og betydningen denne evnen har vist seg å ha for den medisinske behandlingen av pasienter, viser at dette er et viktig fagområde med hensyn til fremtidig medisinsk behandling og utvikling.

Pedersens beskrivelse av «mis-

\section{REFERANSER}

1. Kåver, A. og Nilsonne, Å.: Tillsammans 2007. Natur och kultur

2. Album, D.; Westin, S.: Do diseases have a prestige hierarchy? A survey among physicians and medical students.

Soc. Sci. Med. 2008;66:182-188

3. Thomee, P.; Währborg. P.; Børjesson, M.; Thomee, R.; Eriksson, B,; Karlsson, J.: Att tro på sig själv-grund før lyckad rehabilitering. Läkartidningen 2009;32:1975-1977 4. Pedersen, R.: Emphaty in medicine. A philosophical hermeneutic reflection. Faculty of Medicine. Universitetet i Oslo, 2010.

5. Ågård, A og Løfmark R.: Att utveckla etisk kompetens-går det? Läkartidningen 2009;52:3507-3509. sing links» i faglitteratur om empati åpner opp for ny utdanningslitteratur. For eksempel litteratur som knytter resultatene av biologisk forskning om speilnevroner til den kliniske erfaringen om hvordan man møter pasienter og pårørende på en tilfredsstillende måte.

Det er også viktig at man i fremtidig forskning knytter pasienters og pårørendes erfaring til behandlingsresultatet. Allerede i dag interesserer man seg for hvordan pasienters tro på seg selv kan gi bedre medisinske resultater. Å lytte til pårørende kan gi bedre resultater. Stigmatiseringen knyttet til psykisk sykdom gjør det spesielt viktig å se nærmere på hvordan empati kommer til uttrykk i møtet mellom helsepersonell og pårørende. Det er viktig å se nærmere på hvilken status forskjellige sykdommer har i samfunnet og hvordan denne statusen påvirkes av mediene. Slik informasjon kan hjelpe oss til å iverksette tiltak for å ivareta mennesker med lavstatussykdommer og stigmatiserte sykdommer bedre, for eksempel pasienter med psykisk sykdom. Det er også viktig og se om det skjer forandringer med hensyn til sykdommenes status i framtiden. Også arbeidsmiljøet kan påvirke måten pasienter blir møtt på, et annet felt som sikkert også blir et viktig forskningsområde $\mathrm{i}$ fremtiden.

Å forske videre på helsepersonells evne til empati og rollen empati spiller, bør spille en rolle i helsearbeidernes utdanning. Dette blir garantert en spennende utfordring som kan bety mye for den fremtidige medisinske utviklingen.
6. Ågård, A.; Lynøe, N.; Nilstun, N. og Sallin, K.: Studenter behøver få träna etik under klinisk praktik. Läkartidningen 2009;52:3503-3506

7. Håkansson Eklund, J.; Batson, C.D.; Chermok, V.L.; Hoyt, J.L. og Ortiz, B.G.: An Additional Antecendent of Empathic Concern: Valuing the Welfare of the Person in Need. J of Personality and Social Psychology 2007;93:65-74

8. Eklund, J.; Andersson-Stråberg, T. og Hansen E.M.: «I've also experienced loss and fear»: Effects of prior similar experience on empathy. Scand J of psychology 2008:50:65-69.

9. Rasoal, C.: Etnocultural Empathy. Measurement, psychometric properties and differences between students in health care education programmes. Linköping University, Department of Behavioural Sciences and Learning, 2009.

10. Pennbrant, S.: Äldre patienters, närståendes och läkares erfarenheter av møtet dem emellan. En studie inom sjukhusvård med ett sociokulturellt perspektiv. Institutionen før vårdvetenskap och hälsa. Sahlgrenska akademinin. Gøteborgs Universitet, 2009.

11. Sjöblom, L.-M.: Närstående i den psykiatriska vården. En kvalitativ studie om erfarenheter av närståendes delaktighet. Mittuniversitetet MID Sweden University, 2010

12. Nilzen, R.: Teorin om spegelneuron førklarar førmågan till empati 2008;32:2193-2195 